\title{
Otoczenie prawne przedsięwzięć rewitalizacyjnych obszarów miejskich a postępowanie administracji publicznej
}

\author{
Tadeusz Biliński, Emilia Kucharczyk
}

\author{
Zaktad Budownictwa Ogólnego i Fizyki budowli, \\ Wydziat Budownictwa, Architektury i Inżynierii Srodowiska, Uniwersytet Zielonogórski, \\ e-mail:t.bilinski@wp.pl,e.kucharczyk@ib.uz.zgora.pl
}

Streszczenie: W publikacji ogólnie scharakteryzowano przedsięwzięcia rewitalizacyjne obszarów miejskich, szczególną uwagę zwracając na ich złożoność i znaczenie, na zrównoważony społeczno-gospodarczy rozwój całej aglomeracji. Zasadniczą jednak wartością opracowania jest kompleksowe i spójne przedstawienie uwarunkowań prawnych w całym procesie przestrzennej reorganizacji miejskich obszarów zabudowanych. Prezentacja poszczególnych, kolejno po sobie następujących aktów normatywnych i dokumentów prawa miejscowego wraz z komentarzem pozwala na pełne, wieloaspektowe spojrzenie na budowę ładu przestrzennego w procesie rewitalizacji obszarów miejskich. Przyporządkowanie poszczególnych kolejno następującym działaniom związanym z realizacją przedsięwzięć rewitalizacyjnych, odpowiednich przepisów prawnych, ułatwia programowanie, planowanie, projektowanie, a w końcu realizacje kompleksowych przedsięwzięć rewitalizacyjnych obszarów miejskich. W tym postępowaniu wyróżniono rolę administracji publicznej, zarówno samorządowej jak i rządowej.

Słowa kluczowe: rewitalizacja, ład przestrzenny, obszar zabudowany, funkcje miasta, otoczenie (oprzyrządowanie) prawne.

\section{Wprowadzenie}

Piękne miasto i przyjazne jego mieszkańcom będzie zawsze atrakcyjne i powszechnie lubiane. Nie wystarcza jednak dobrze opracowany w przeszłości miejscowy plan zagospodarowania przestrzennego miasta i dobrze zaprogramowana strategia jego rozwoju. Nieodzowne jest ciągłe dbanie o stan techniczny obiektów budowlanych, ich estetykę, o dostosowywanie ich do współczesnych wymogów cywilizacyjnych, dbając o funkcjonalność przestrzenną miasta i harmonię jego zabudowy. Trzeba także mieć na uwadze aktualne, zmieniające się potrzeby i oczekiwania mieszkańców oraz co bardzo istotne, perspektywiczną politykę rozwoju miasta.

Realizacja powyższych celów wymaga podejmowania bardzo różnych przedsięwzięć (rewitalizacyjnych, inwestycyjno-budowlanych) na ogół w bardzo trudnych warunkach i zmieniających się w czasie uwarunkowań. Stąd też realizacja poszczególnych zadań budowlanych napotyka na liczne trudności prawno-organizacyjne, wynikające także często z niewłaściwego postępowania bezpośrednich uczestników procesu budowlanego, czy organów administracji publicznej. Przepisom prawnym regulującym procesy rewitalizacyjne oraz temu ostatniemu zagadnieniu poświęcona jest ta publikacja. [1] 


\section{Przedsięwzięcia inwestycyjno-budowlane w procesie rewitalizacji obszarów miejskich}

W świetle ogólnego omówienia specyfiki przedsięwzięć rewitalizacyjnych i ich otoczenia prawnego, widoczna jest ich złożoność w czasie i przestrzeni, a lokalnie występujące uwarunkowania indywidualnego przedsięwzięcia rewitalizacyjnego prowadzą często do znacznych utrudnień w procesie ich realizacji. Realizacja przedsięwzięć rewitalizacyjnych obszarów miejskich jest trudna , uciążliwa, znacznie trudniejsza od realizacji przedsięwzięć inwestycyjno-budowlanych na terenach niezurbanizowanych, wolnych od jakichkolwiek zabudowań.

Często jest bardzo ograniczony plac budowy, nieodzowne jest zabezpieczenie budynków sąsiadujących, istniejącej roślinności, szczególnie pomników przyrody, przekładanie instalacji i urządzeń infrastruktury technicznej, a w przypadku obiektów zabytkowych lub terenów objętych opieką konserwatorską, konieczna jest pełna współpraca z konserwatorem zabytków. W trakcie realizacji poszczególnych zadań budowlanych zdarzają się często nieprzewidywane sytuacje, jak konieczność wymiany elementów konstrukcyjnych w obiektach poddawanych renowacji, czy zaskakujące odkrycia archeologiczne. Stąd też, nie tylko programowanie planowanie i projektowanie przedsięwzięć rewitalizacyjnych jest trudne i uciążliwe, ale także realizacja zamierzeń rewitalizacyjnych przysparza inwestorom i wykonawcom wiele trudności.

Spośród wielu różnych przedsięwzięć rewitalizacyjnych, na szczególną uwagę zasługują działania prowadzące do przeobrażania obszaru miejskiego i doprowadzenie do ładu przestrzennego.

Ponadto należy zaznaczyć, że znaczna część ma istotne znaczenie dla funkcjonalności miasta, dla jego zrównoważonego rozwoju.

Opracowywanie miejscowych planów zagospodarowania przestrzennego, często dla małych, ograniczonych obszarów przewidzianych do rewitalizacji, jest niewłaściwe, nawet niezależnie od jakości wykonania całego przedsięwzięcia rewitalizacyjnego, prowadzi do dysfunkcji i niespójności obszaru miejskiego. Jeśli nie od razu, to na pewno w najbliższej perspektywie rozwoju. Nieodzowne jest zatem podejmowanie przedsięwzięć rewitalizacyjnych wyłącznie o aktualny miejscowy plan zagospodarowania przestrzennego całego miasta, a w przypadku wielkich aglomeracji, poszczególnych dzielnic. Trzeba jeszcze wspomnieć, że pełne zabudowywanie wolnych przestrzeni miejskich jest błędem, szczególnie w aspekcie potrzeb przyszłych pokoleń.

Istotne znaczenie dla funkcjonowania miasta ma układ komunikacyjny, węzły komunikacyjne, centra przesiadkowe, automatyczne sterowanie ruchem ulicznym pojazdów. Dzisiaj, coraz częściej, wprowadzane jest wyłączanie centrów miast z ruchu pojazdów mechanicznych, całkowite lub częściowe, budowa ścieżek rowerowych i pasaży dla pieszych. Wszystkie takie działania usprawniają komunikację i kształtują nowy ład przestrzenny.

Aktualnie najpowszechniejszymi są przedsięwzięcia termomodernizacyjne. Stanowi to realizację strategicznego celu zrównoważonego rozwoju, jakim jest racjonalne korzystanie $\mathrm{z}$ energii. Natomiast, w niewielkim stopniu w procesie rewitalizacji miast, renowacji budynków, wykorzystuje się odnawialne źródła energii cieplnej słońca (kolektory słoneczne, ogniwa fotowoltaiczne), pionowe lub poziome źródła geotermiczne ziemi.

Istotne są także działania konserwatorskie obiektów zabytkowych, ujętych w rejestrze zabytków. Obiekty materialnego dziedzictwa narodowego wymagają bezpośredniej opieki, ale także, co jest istotne, odpowiedniego zabezpieczenia w przypadku prowadzenia robót budowlanych i instalacyjnych w bezpośrednim ich sąsiedztwie. 
Odrębnym problemem w procesie rewitalizacji obszarów miejskich, równie istotnym, jest ochrona zieleni, czy ewentualnie jej kompensata, ochrona parków, skwerów, nawet niewielkich enklaw zieleni. Ważne jest zachowanie ciągów ekologicznych, a jeśli jest możliwość, ich zwiększania. Ważna jest także odbudowa zdegradowanych naturalnych obszarów zieleni będących w obrębie miasta. Ochrona przyrody to także podstawowe założenie zrównoważonego rozwoju [2].

Z przedstawionych ogólnie zakresu przedsięwzięć rewitalizacyjnych wynika, że szczególne znaczenie ma planowanie i zagospodarowanie przestrzenne. Nieodzowna jest zatem pełna znajomość stanu prawnego podejmowania i realizacji przedsięwzięć rewitalizacyjnych. Dodatkowo, mając na uwadze konieczność długoletnich studiów, badań i konsultacji profesjonalnych i społecznych na etapie programowania rewitalizacji obszarów miejskich i to ze znacznym wyprzedzeniem, niezbędne jest często inicjowanie i współdziałanie różnych instytucji i jednostek gospodarczych w tworzeniu prawa miejscowego i opracowań strategicznych dotyczących funkcjonalno-przestrzennego rozwoju miast.

\section{Podstawy prawne procesów przedsięwzięć rewitalizacyjnych z komentarzem}

Jednostki organów samorządowych i administracji rządowej są odpowiedzialne za postępowanie w sprawach przeznaczania terenów na określone cele oraz ustalanie zasad ich zagospodarowania i zabudowy, przyjmując ład przestrzenny i zrównoważony rozwój za podstawę tych działań [3].

Podstawą tworzenia ładu przestrzennego zagospodarowania przestrzeni są przede wszystkim miejscowe plany zagospodarowania przestrzennego, które opracowane są na podstawie wcześniej uchwalonego studium uwarunkowań i kierunków zagospodarowania przestrzennego gminy.

Podstawą do opracowania studium uwarunkowań i kierunków zagospodarowania przestrzennego, jest polityka przestrzenna rozwoju gminy wyrażona najczęściej w strategii jej rozwoju. Strategia rozwoju gminy informuje o warunkach podejmowania i realizacji wszelkich działań w gminie, w tym formułowaniu kolejnych wieloletnich planów inwestycyjnych. Strategia stanowi jednocześnie podstawę do kształtowania współpracy podmiotów w realizacji wytyczonych celów.

Jednakże ustalenia strategii rozwoju nie zobowiązują organów samorządowych do jej bezwzględnego przestrzegania przy opracowaniu studium uwarunkowań i kierunków zagospodarowania przestrzennego.

W studium uwarunkowań i kierunków zagospodarowania przestrzennego między innymi powinny być wyznaczone obszary rozmieszczenia inwestycji celu publicznego o znaczeniu krajowym, wojewódzkim i metropolitalnym, ujętych w planie zagospodarowania przestrzennego województwa. Jeżeli przewiduje się na terenie gminy budowę obiektów handlowych o powierzchni zabudowy przekraczającej $2000 \mathrm{~m}^{2}$, to w Studium powinny być wyznaczone obszary pod tą zabudowę. W przypadku gdy, na obszarze gminy przewiduje się wyznaczenie obszarów, na których rozmieszczone będą urządzenia wytwarzające energię z odnawialnych źródeł energii o mocy przekraczającej $100 \mathrm{~kW}$, a także ich stref ochronnych związanych $\mathrm{z}$ ograniczeniami w zabudowie oraz zagospodarowaniu i użytkowaniu terenu, w Studium ustala się ich rozmieszczenie.

Ustalenia studium są wiążące dla organów gminy przy sporządzaniu miejscowych planów. 
Należy jednak wziąć pod uwagę charakter Studium, które nie może zawierać wszystkich szczegółowych ustaleń i sposobów zagospodarowania przestrzennego, ponieważ jest to zadaniem planu miejscowego, który ma rozwinać i uszczegółowić główne wytyczne i kierunki określone w Studium. Wymagana przez ustawę zgodność unormowań planu zagospodarowania przestrzennego z ustaleniami studium uwarunkowań i kierunków rozwoju gminy nie oznacza ich pełnej tożsamości albowiem istota obu aktów jest odmienna, mają one odrębne cele i skierowane są do innych adresatów, a więc i ich stopień szczegółowości jest inny. Nie oznacza to jednak, że dopuszcza się pełną dowolność w kształtowaniu przeznaczenia i warunków zagospodarowania w planie zagospodarowania przestrzennego przez organy planistyczne. Są one bowiem związane uchwalonym wcześniej przez siebie studium. Stąd zakres swobody w kształtowaniu ustaleń planu nie jest dowolny i treść Studium niesie także pewne ograniczenia. Przykładowo, gdy w Studium zostały określone pewne współczynniki lub wartości, to mają one charakter graniczny (maksymalny lub minimalny). Nie można przyjmować, że mają one charakter orientacyjny dla różnych rodzajów zabudowy w poszczególnych strefach funkcjonalnych, bowiem określone w Studium wskaźniki mogą być niższe, ale nie mogą przekraczać wskazanych wartości tych wskaźników.

Odmienna interpretacja tych zapisów Studium nie oznaczałaby swobody przy tworzeniu i uchwalaniu miejscowego planu zagospodarowania przestrzennego, lecz skutkowałaby całkowitą ich dowolnością w tym zakresie, co związanie z ustaleniami wynikającymi ze Studium byłoby fasadowym.

Studium nie jest aktem prawa miejscowego (art. 9 [4]).

Miejscowy plan zagospodarowania przestrzennego ustala przeznaczenia terenów, rozmieszczenie inwestycji celu publicznego oraz określenie sposobów zagospodarowania i warunków zabudowy terenu (art. 15 [4]).

W miejscowym planie między innymi, mając na uwadze temat publikacji określa się obowiązkowo:

1) przeznaczenie terenów oraz linie rozgraniczające tereny o różnym przeznaczeniu lub różnych zasadach zagospodarowania;

2) zasady ochrony i kształtowania ładu przestrzennego;

3) zasady ochrony środowiska, przyrody i krajobrazu;

3a) zasady kształtowania krajobrazu;

4) zasady ochrony dziedzictwa kulturowego i zabytków, w tym krajobrazów kulturowych, oraz dóbr kultury współczesnej;

W przypadku braku miejscowego planu zagospodarowania przestrzennego, sposób zagospodarowania i warunki zabudowy zostają określone w decyzji o warunkach zabudowy i zagospodarowania terenu, a w przypadku inwestycji celu publicznego w decyzji o lokalizacji inwestycji celu publicznego.

Miejscowy plan zagospodarowania przestrzennego jest aktem prawa miejscowego.

Decyzja o warunkach zabudowy i zagospodarowaniu terenu, wydana zostanie w przypadku braku miejscowego planu zagospodarowania przestrzennego lub utraty jego aktualności, albo nastąpi zmiana zagospodarowania działki lub terenu, polegająca na budowie obiektu budowlanego lub wykonaniu innych robót budowlanych, a także zmiana sposobu użytkowania obiektu budowlanego lub jego części. Ponadto regulacją tą objęte są obiekty budowlane, nie wymagające pozwolenia na budowę, a wymagające dokonanie zgłoszenia z projektem budowlanym (budynki mieszkalne jednorodzinne, stacje transformatorowe o powierzchni zabudowy do $35 \mathrm{~m}^{2}$ - art. 29 ust. 1 pkt 1a, 2b ustawy Prawo budowlane [5]). 
Wydanie decyzji o warunkach zabudowy jest możliwe jedynie w przypadku spełnienia następujących warunków łącznie:

1) co najmniej jedna działka sąsiednia, dostępna $z$ tej samej drogi publicznej, jest zabudowana w sposób pozwalający na określenie wymagań dotyczących nowej zabudowy w zakresie kontynuacji funkcji, parametrów, cech i wskaźników kształtowania zabudowy oraz zagospodarowania terenu, w tym gabarytów i formy architektonicznej obiektów budowlanych, linii zabudowy oraz intensywności wykorzystania terenu;

2) teren ma dostęp do drogi publicznej;

3) istniejące lub projektowane uzbrojenie terenu, jeżeli wykonanie uzbrojenia terenu zostanie zagwarantowane $\mathrm{w}$ drodze umowy zawartej między właściwą jednostką organizacyjną a inwestorem, jest wystarczające dla zamierzenia budowlanego

4) teren nie wymaga uzyskania zgody na zmianę przeznaczenia gruntów rolnych i leśnych na cele nierolnicze i nieleśne albo jest objęty zgodą uzyskaną przy sporządzaniu miejscowych planów, które utraciły moc ,

5) decyzja jest zgodna z przepisami odrębnymi (art. 61 [4]).

Decyzja o lokalizacji inwestycji celu publicznego. Cele publiczne zostały określone w art. 6 ustawy z 21 sierpnia 1997 r. o gospodarce nieruchomościami [6]. Dotyczą one inwestycji drogowych, kolejowych, innych związanych z infrastrukturą techniczną, ochroną środowiska, urządzeń przesyłowych, obiektów szkolnych, leczniczych, czy też związanych z funkcjonowaniem administracji publicznej. Inwestycją celu publicznego są działania o znaczeniu lokalnym, ponadlokalnym i krajowym, stanowiące realizację celów publicznych. Inwestycja celu publicznego jest lokalizowana na podstawie planu miejscowego, a w przypadku jego braku - w drodze decyzji o ustaleniu lokalizacji inwestycji celu publicznego.

Nie wymagają wydania decyzji o ustaleniu lokalizacji inwestycji celu publicznego roboty budowlane:

1) polegające na remoncie, montażu lub przebudowie, jeżeli nie powodują zmiany sposobu zagospodarowania terenu i użytkowania obiektu budowlanego oraz nie zmieniają jego formy architektonicznej, a także nie są zaliczone do przedsięwzięć wymagających przeprowadzenia postępowania w sprawie oceny oddziaływania na środowisko, w rozumieniu przepisów o ochronie środowiska [7], albo

2) niewymagające pozwolenia na budowę z wyjątkiem budowy sieci, o których mowa w art. 29 ust. 1 pkt 19a stawy z dnia 7 lipca 1994 r. - Prawo budowlane, gdzie wymagane jest uzyskanie decyzji o ustaleniu lokalizacji inwestycji celu publicznego [5].

Pomimo szczegółowych norm w ustawie o planowaniu i zagospodarowaniu przestrzennym w odniesieniu do decyzji o warunkach zabudowy i zagospodarowania terenu można zaobserwować dużą ignorancję administracji publicznej co do przestrzegania obowiązujących zasad przy rozstrzygnięciach w decyzjach o warunkach zabudowy.

Często spotykamy się z wydaniem decyzji o warunkach zabudowy, gdzie postępowania $w$ tych sprawach obarczone są błędami formalnymi jak: niepodjęcie przez organy działania zmierzającego do dokładnego wyjaśnienia stanu faktycznego sprawy (art. 7 kpa.), brak zebrania i rozpatrzenia całego materiału dowodowego w sposób wyczerpujący (art. $77 \S 1 \mathrm{kpa}$ ), naruszenie art. $28 \mathrm{kpa}$ poprzez niewłaściwe określenie stron postępowania oraz nie dokonanie oceny, czy dana okoliczność została udowodniona (art. 80 k.p.a.)[8].

Zdarzają się też naruszenia prawa materialnego przez organy administracji publicznej do których często należą. nieprawidłowości takie jak: wyznaczenie linii zabudowy, 
uznaniowy wskaźnik zabudowy, niedokładna analiza nowej zabudowy w odniesieniu do istniejącego stanu zabudowy itp.

(Wyrok NSA z 2016-06-21sygn.II OSK 2593/14).

Nieprawidłowości często występują przy określaniu zasady „dobrego sąsiedztwa”, zwanej także zasadą podobieństwa lub kontynuacji, którą wskazuje Ustawa o planowaniu i zagospodarowaniu przestrzennym. Ustawa nie definiuje pojęcia „działki sąsiedniej”, a organy administracji publicznej ograniczają się do działki przyległej do działki inwestora. Aby stwierdzić, czy możliwe jest określenie dla danego zamierzenia warunków zabudowy, należy dokonać analizy i ustalić, czy zabudowa na terenie sąsiadującym z terenem, na którym inwestor zamierza zrealizować nową zabudowę, jest taka, że pozwala na określenie wymagań dotyczących nowej zabudowy. Zatem, by można było ustalić warunki dla nowej zabudowy, czyli rozważyć, czy są wymagane prawem przesłanki, na terenie sąsiadującym musi znajdować się co najmniej jeden obiekt budowlany, gdyż tylko wówczas będzie możliwe ustalenie kontynuacji funkcji, parametrów, cech i wskaźników kształtowania zabudowy oraz zagospodarowania terenu, w tym gabarytów i formy architektonicznej obiektu budowlanego, linii zabudowy oraz intensywności wykorzystania terenu. Brak na określonym obszarze obiektu o podobnych parametrach skutkuje najczęściej odmową wydania decyzji o warunkach zabudowy. W świetle orzecznictwa NSA przez pojęcie „działka sąsiednia”, należy rozumieć nieruchomość znajdującą się w pewnym obszarze wokół działki, na której ma powstać planowana inwestycja, tworzącym pewną urbanistyczną całość. Podkreśla się, że pojęcia „działki sąsiedniej” nie można ograniczać do działki przyległej do działki inwestora, lecz odnieść je należy do pewnego obszaru tworzącego urbanistyczną całość, pozwalającą organowi na dokonanie oceny możliwości zrealizowania planowanej inwestycji przy zachowaniu ustawowych warunków wynikających z art. 61 ustawy[4].

(Wyrok NSA z dnia 17 kwietnia 2007 r., sygn. akt II OSK 646/2007)

(Wyrok NSA z dnia 16 stycznia 2007 r. sygn. akt II OSK 172/2006)

Rady Gmin posiadają również uprawnienie do ustalenia w formie uchwały zasady i warunki sytuowania obiektów małej architektury, tablic reklamowych i urządzeń reklamowych oraz ogrodzeń, ich gabaryty, standardy jakościowe oraz rodzaje materiałów budowlanych, z jakich mogą być wykonane a także mogą ustalić zakaz sytuowania ogrodzeń oraz tablic reklamowych i urządzeń reklamowych, z wyłączeniem szyldów ( art. 37a ustawy [4]).

Uchwała taka jest aktem prawa miejscowego.

Rewitalizacja. W dniu 18 listopada 2015 r. weszła w życie Ustawa z dnia 9 października 2015 r. - o rewitalizacji [9]. Jest to nowy akt prawny, który przyczyni się do likwidacji występujących obecnie barier organizacyjnych procesów rewitalizacji, w szczególności takich jak: wykorzystywanie programów rewitalizacji wyłącznie jako narzędzia pozyskiwania środków europejskich, a nie sformułowania realnych działań na rzecz poprawy sytuacji w obszarze kryzysowym, brak kompleksowości prowadzonych działań, sprowadzanie rewitalizacji do procesu budowlanego, pomijanie czynników społecznych w przygotowaniu i realizacji procesów rewitalizacji, brak niezbędnej koordynacji między instytucjami publicznymi przy opracowywaniu programów rewitalizacji

Rewitalizacja to działania prowadzone na istniejących przestrzeniach zurbanizowanych, działania związane $\mathrm{z}$ realizacją nowych zespołów zabudowy na terenach wolnych od zabudowy. W ramach rewitalizacji często nieodzowna będzie reorganizacja zdezorganizowanej przestrzeni miejskiej, odbudowa zdegradowanych obszarów najczęściej starych centrów miast, czy też obszary zdewastowanych i wyburzonych budynków. Nie powinny pozostać pustymi obszarami, zatem podejmowana jest rewitalizacja takich terenów. Również 
w obszarze rewitalizacji znajdują się działania obejmujące restrukturyzacje infrastruktury, terenów przemysłowych i często terenów po wojskowych.

W przypadku odbudowy, przebudowy, remontów czy restrukturyzacji obiektów budowlanych musimy pamiętać, że zachowany powinien być ład i porządek przy zagospodarowaniu przestrzennym obszarów, które będą podlegały rewitalizacji.

Do zadań własnych samorządu gminnego należą sprawy dotyczące ładu przestrzennego, gospodarki nieruchomościami, ochrony środowiska i przyrody oraz gospodarki wodnej [3]. Ponadto regulacje prawne w sprawach rewitalizacji zostały określone w ustawie o rewitalizacji [9], w świetle których przygotowanie, koordynowanie i tworzenie warunków do prowadzenia rewitalizacji, a także jej prowadzenie w zakresie właściwości gminy, stanowią jej zadania własne.

Samorząd gminny na podstawie opracowanego i uchwalonego gminnego programu rewitalizacji w których wskazany jest sposób jego realizacji w zakresie planowania i zagospodarowania przestrzennego, w tym: wskazanie zakresu niezbędnych zmian w studium uwarunkowań i kierunków zagospodarowania przestrzennego gminy, wskazanie miejscowych planów zagospodarowania przestrzennego koniecznych do uchwalenia albo zmiany, a w przypadku wskazania konieczności uchwalenia miejscowego planu rewitalizacji, o którym mowa w art. $37 f$ ust. 1 [4], wskazanie granic obszarów, dla których plan ten będzie objęty łącznie z procedurą scaleń i podziałów nieruchomości, a także wytyczne w zakresie ustaleń tego planu. [4]

Rada gminy może ustanowić na obszarze rewitalizacji zakaz wydawania decyzji o warunkach zabudowy oraz dla wszystkich albo określonych zmian sposobu zagospodarowania terenu wymagających tej decyzji, w tym zmian sposobu użytkowania obiektu budowlanego lub jego części, jeżeli stan zagospodarowania obszaru rewitalizacji oraz stopień jego pokrycia miejscowymi planami zagospodarowania przestrzennego wskazują, że nieustanowienie zakazu może doprowadzić do niekorzystnych zmian w zagospodarowaniu obszaru rewitalizacji, pogłębiających niekorzystne zjawiska ( art. 30 [9]).

Dotyczy to w szczególności zjawisk w zakresie przestrzenno-funkcjonalnym np. niewystarczającego wyposażenia w infrastrukturę techniczną lub jej złego stanu technicznego, infrastruktury społecznej, braku dostępu do podstawowych usług lub ich niskiej jakości, niedostosowania rozwiązań urbanistycznych do zmieniających się funkcji obszaru, albo technicznych jak degradacja stanu technicznego obiektów budowlanych w tym o przeznaczeniu mieszkaniowym, czy wadliwym funkcjonowaniu rozwiązań technicznych uniemożliwiających efektywne korzystanie z obiektów budowlanych, w szczególności w zakresie energooszczędności i ochrony środowiska.

Rada gminy może uchwalić dla obszaru rewitalizacji miejscowy plan rewitalizacji, jeżeli uchwalony został gminny program rewitalizacji.

W miejscowym planie rewitalizacji można określić, w odniesieniu do nieruchomości niezabudowanej, że warunkiem realizacji na niej inwestycji głównej jest zobowiązanie się inwestora do budowy na swój koszt i do nieodpłatnego przekazania na rzecz gminy inwestycji uzupełniających w postaci infrastruktury technicznej, społecznej lub lokali mieszkalnych - w zakresie wskazanym w tym planie. Inwestycją główną nie może być inwestycja celu publicznego ( art. 37 i ust. 2 [4]).

Przy inwestycjach uzupełniających możliwe jest również zobowiązanie inwestora do budowy na swój koszt i do nieodpłatnego przekazania na rzecz gminy lokali innych niż mieszkalne przeznaczonych na potrzeby działalności kulturalnej, społecznej, edukacyjnej lub sportowej, wykonywanej przez podmioty prowadzące działalność na obszarze rewitalizacji, których głównym celem nie jest osiągnięcie zysku. 
Miejscowy plan rewitalizacji jest szczególną formą planu miejscowego.

Realizacja inwestycji budowlanej na obszarach rewitalizacyjnych jest podporządkowana wymaganiom określonym w miejscowym planie rewitalizacji bądź miejscowym planie zagospodarowania przestrzennego.

Gdy gmina będzie zamierzała realizować zadania własne, rada gminy wyznaczy, w drodze uchwały, z własnej inicjatywy albo na wniosek wójta, burmistrza albo prezydenta miasta, obszar zdegradowany i obszar rewitalizacji. Obszar może zostać wskazany jako zdegradowany, jeśli znajduje się w stanie kryzysowym z powodu koncentracji negatywnych zjawisk społecznych, w szczególności bezrobocia, ubóstwa, przestępczości, niskiego poziomu edukacji lub kapitału społecznego, a także niewystarczającego poziomu uczestnictwa w życiu publicznym i kulturalnym oraz gdy występuje na nim co najmniej jedno z negatywnych zjawisk gospodarczych, środowiskowych, przestrzenno-funkcjonalnych i technicznych.

Uchwała ta będzie aktem prawa miejscowego.

Mimo, że gminy posiadają możliwości ustawiania programów, planów rewitalizacji w oparciu o ustawy, działania są niewystarczające. Do rzadkości należy pełne opracowanie programów rewitalizacji, planów rewitalizacji, a efekcie brak jest realizacji kompleksowych przedsięwzięć rewitalizacyjnych na dużych obszarach miejskich.

Realizacja przedsięwzięć rewitalizacyjnych powinna być spójna na całym obszarze objętym programem. Częściowa realizacja programu rewitalizacji czyli wybranych zadań rozrzuconych na całym obszarze stanowiących przy pozostawieniu pozostałych zadań równie ważnych na „lepsze czasy” jest nieracjonalna, a czasami nawet nieskuteczna. Niespójne działania nie przynoszą bowiem pożądanego efektu, skutku społeczno-ekonomicznego. Trzeba jednak też pamiętać o tym, że pozostawienie wolnych niezagospodarowanych przestrzeni może być celowe dla zaspokojenia potrzeb przyszłych pokoleń.

\section{Podsumowanie}

W świetle przedstawionych i omówionych przykładów realizacji różnych przedsięwzięć rewitalizacyjnych obszarów miejskich, administracja publiczna nie jest zwolniona z odpowiedzialności za ład przestrzenny, za jakość rewitalizowanej przestrzeni, za końcowe efekty społeczno-gospodarcze. Nie wystarczy dbałość o stan techniczny obiektów budowlanych, o ich estetykę. Nieodzowna jest harmonia zabudowy i funkcjonalności przestrzeni . Każde miasto, niezależnie od poziomu jego rozwoju, wymaga renowacji, modernizacji i jej zabudowy zgodnie z postępującym rozwojem cywilizacyjnym. W przeciwnym przypadku, jego postępująca degradacja doprowadzi do jego upadłości. W publikacji przedstawiono kompleksowo obowiązujące „oprzyrządowanie prawne” dla przedsięwzięć rewitalizacyjnych dużych obszarów miejskich. Tylko i wyłącznie poprzez realizację dużych programów rewitalizacji obszarów miejskich można osiągnąć cele strategiczne zrównoważonego rozwoju.

\section{Literatura}

[1] Biliński T., Kucharczyk E. Prawo budowlane z omówienie i komentarzem - stan prawny na 1 stycznia 2016. Uniwersytet Zielonogórski, Oficyna Wydawnicza 2016.

[2] Biliński T. Kryteria i uwarunkowania programowania przedsięwzięć rewitalizacyjnych obszarów miejskich. Przegląd budowlany, nr 3, 2018. 


\title{
Akty prawne:
}

[3] Ustawa z dnia 8 marca 1990 r. - o samorządzie gminnym ( Dz.U. 2018, poz. 994 - jednolity tekst).

[4] Ustawa z 27 marca 2003 r.- o planowaniu i zagospodarowaniu przestrzennym (Dz.U. 2017, poz. 1073, jednolity tekst, z późn. zm.).

[5] Ustawa z dnia 7 lipca 1994 r. - Prawo budowlane (Dz.U. 2018 poz. 1202 - jednolity tekst, z późn. zm.).

[6] Ustawa z dnia 21 sierpnia 1997 r. - o gospodarce nieruchomościami (Dz.U. 2018, poz. 121,jednolity tekst).

[7] Ustawa z dnia 27 kwietnia 2001 r.- Prawo ochrony środowiska (Dz.U. 2018, poz. 799, jednolity tekst z późn. zm.).

[8] Ustawa z dnia 14 czerwca 1960 r.- Kodeks postępowania administracyjnego (Dz.U. 2017, poz. 1257, jednolity tekst z późn. zm).

[9] Ustawa z dnia 9 października 2015 r. - o rewitalizacji (Dz.U. 2018, poz. 1398 - tekst jednolity).

\section{The legal environment of revitalization ventures of urban areas and the proceeding of public administration}

\author{
Tadeusz Biliński, Emilia Kucharczyk \\ Department of General Building and Building Physics, Faculty of Civil Engineering, \\ Architecture and Environmental Engineering, University of Zielona Góra, \\ e-mail: t.bilinski@wp.pl,e.kucharczyk@ib.uz.zgora.pl
}

\begin{abstract}
The paper presents in general characterization of revitalization ventures of urban areas, special attention paying to their complexity and importance to the sustainable socio-economic development of the whole agglomeration. The fundamental value of this study is a comprehensive and consistent presentation of legal conditions in the entire spatial reorganization process of urban built-up areas. Presentation of individual, consecutive, normative acts and local law documents together with commentary allows a full, multi-faceted view of the construction of spatial order in the process of urban revitalization. The assignment of the following to each of the following activities related to the implementation of revitalization projects, relevant legal provisions, facilitates programming, planning, designing, and finally the implementation of comprehensive revitalization projects of urban areas. In this proceeding the role of public administration, both local government and governmental, was distinguished.
\end{abstract}

Keywords: revitalization, spatial order, urban area, functions of the city, legal environment (instrumentation). 
